\title{
Economic potential of Ukraine: assessment and forecasting
}

\author{
Olena Dymchenko ${ }^{1 *}$, Olha Rudachenko ${ }^{1}$, Valeriya Yesina $^{2}$, and Iurii Tararuiev ${ }^{1}$ \\ ${ }^{1}$ O.M.Beketov National University of Urban Economy in Kharkiv, Department of entrepreneurship \& \\ business administration, 61002, Marshal Bazhanov Street, 17, Kharkiv, Ukraine \\ ${ }^{2}$ O.M.Beketov National University of Urban Economy in Kharkiv, Department of economics, 61002, \\ Marshal Bazhanov Street, 17, Kharkiv, Ukraine
}

\begin{abstract}
Based on the results of the open statistical data analysis, the paper justifies indicators for an integral assessment of the economic potential of Ukraine by types of economic activity of business entities. Since the potential is implemented in the future, the paper uses trend analysis to determine the prospective values of previously selected indicators. At the same time, some relative indicators were decomposed into absolute elements (as each of the absolute indicators has its own dynamics of changes). Stepwise, logarithmic, exponential, and other dependencies are used to predict indicators. In addition, the prospective values of indicators were normalized in order to get the correct calculation of the integral indicator in the paper. The integral indicator of the economic potential of Ukraine for each type of economic activity of business entities for the year 2022 is calculated as a result of generalizing the normalized values of prospective indicators. The calculation results can be used to distribute budget funds that are planned to be used for ensuring the longterm development of the Ukrainian economy sectors.
\end{abstract}

\section{Introduction}

Conducting an assessment of the current and prospective level of industry potential is an important strategic task, which implementation involves the current state of business entities analysis in the context of economic sectors and allows identifying the most promising industries to ensure priority financial and resource support for the innovative development of such industries. The need to identify the most promising sectors of the economy is resulted from such factors as: a) limited financing of sectoral development using budget funds; b) the need to obtain a significant economic effect from the investment of public funds in order to improve the efficiency of investment. This explains the choice of the research topic.

A significant number of scientific papers are devoted to the problems of assessing and improving economic potential. For example, in the works of foreign scientists methods for quantitative assessment of global real economic activity are analyzed.

\footnotetext{
* Corresponding author: dymchenkoov@gmail.com
} 
The research proposes a method that can be used to model prices for manufactured goods and develop structural models of commodity markets and to predict prices for commodities [1-3].

The researches $[4,5]$ analyse and models the ways of development of these territories by increasing the efficiency of investments of budget funds in scientific, technical and innovative developments for certain industries. The study [6] conducted an extensive analysis of the forms, methods and sources of funding for innovation and research, focused on areas of research depending on the size of enterprises conducting R\&D.

Taking into account the above, the aim of the study is to formulate and apply a methodological approach to the integral assessment of the economic potential of Ukraine.

\section{Investigation stages and methods}

Let us consider the main investigation stages, taking into account the methods which were used.

1. The choice of indicators for assessing the economic potential of the Ukrainian economy. For the investigation, one used statistical information of the State statistics service of Ukraine, that reflects the current state of business entities by type of economic activity [7]. Indicators were selected based on the analysis of official data, they generally characterize the economic potential of industries and will be used for its integral assessment (Table 1).

Table 1. Indicators for assessing economic potential.

\begin{tabular}{|c|c|c|}
\hline Indicator`s name & $\begin{array}{c}\text { Units of } \\
\text { measurement }\end{array}$ & Economic content \\
\hline $\begin{array}{c}\text { Profitability of operating activities of } \\
\text { enterprises }\end{array}$ & unit share & \multirow{3}{*}{$\begin{array}{l}\text { characterizes the efficiency of } \\
\text { business entities by type of } \\
\text { economic activity }\end{array}$} \\
\hline Financial results of enterprises & Million UAH & \\
\hline Specific yield & unit share & \\
\hline Capital investment & Million UAH & \multirow{3}{*}{$\begin{array}{l}\text { reflects the volume of } \\
\text { investment activity of business } \\
\text { entities }\end{array}$} \\
\hline Capital investments in progress & Million UAH & \\
\hline Current financial investments & Million UAH & \\
\hline Absolute liquidity ratio & unit share & \multirow{3}{*}{$\begin{array}{l}\text { describes the financial state } \\
\text { and use of fixed assets of } \\
\text { business entities }\end{array}$} \\
\hline Coefficient of autonomy & unit share & \\
\hline Physical wear ratio of capital assets & Million UAH & \\
\hline
\end{tabular}

Some of these indicators are relative, so one has to provide formulas for calculating them (1-4):

$$
\begin{aligned}
& P_{o p}=N P-E_{o p} \\
& S P=I / E \\
& L a=C / C L \\
& C a=E / T C
\end{aligned}
$$


where: $P_{o p}$ - operating profit margin; $N P$ - net profit; $E_{o p}$ - operating expenses; $S P$ specific profitability; $I$ and $E$ - income and expenses; $L_{a}$ - absolute liquidity; $C$ - cash; $C L$ - current liabilities; $\mathrm{C}_{a}$ - coefficient of autonomy; $E$ - equity; $T C$ - total capital.

2. Indicators forecasting. Potential, as an economic category, denotes the expected opportunities of enterprises and other business entities, so only a long-term assessment of economic potential has practical importance (this also involves the use of quantitative forecasting tools). When comparing the most well-known forecasting methods, trend analysis was chosen to achieve the goals of the investigation, it allows to calculate the values of indicators using trend equations (while the period sequence number acts as a variable). Typical trend equations used to calculate prospective values of economic indicators are presented below (5-8).

$$
\begin{aligned}
& y=k \ln (x)+b \\
& y=k x^{b} \\
& y=b e^{k x} \\
& y=k x+b
\end{aligned}
$$

where: $y$ - forecasting value of the indicator; $x$ - variable value of the trend equation,

\begin{tabular}{|c|c|c|}
\hline \multirow{2}{*}{ Indicator name } & \multicolumn{2}{|c|}{ Equation of trends by type of economic activity } \\
\hline & $\begin{array}{l}\text { Professional, scientific } \\
\text { and technical activities }\end{array}$ & Education \\
\hline $\begin{array}{c}\text { Profitability of enterprises operating } \\
\text { activities }\end{array}$ & $y=0,2767 \ln (x)-0,2337$ & $y=0,0563 x^{-0,081}$ \\
\hline Financial results of enterprises & $y=66503 \ln (x)-71725$ & $\mathrm{y}=55,002 \mathrm{e}^{0,1603 \mathrm{x}}$ \\
\hline Income & $y=25828 x+236102$ & $\mathrm{y}=1505,5 \mathrm{e}^{0,1998 \mathrm{x}}$ \\
\hline Expenses & $y=-34520 \ln (x)+361339$ & $y=1453,8 e^{0,2006 x}$ \\
\hline Capital investment & $y=2173,7 e^{0,3287 x}$ & $y=779,49 x^{1,0527}$ \\
\hline Capital investments in progress & $y=18289 e^{0,0709 x}$ & $y=63,807 x^{0,1691}$ \\
\hline Current financial investments & $y=25983 x^{-0,208}$ & $y=2,635 x+4,465$ \\
\hline Funds & $y=3061 x+20307$ & $y=209,05 x^{0,453}$ \\
\hline Current liabilities & $\mathrm{y}=182742 \mathrm{e}^{0,1325 \mathrm{x}}$ & $y=300,3 \ln (x)+498,54$ \\
\hline Equity & $\mathrm{y}=203513 \ln (\mathrm{x})+277394$ & $y=1483,4 e^{0,0625 x}$ \\
\hline Total capital & $y=267267 \ln (x)+581304$ & $y=2193,8 x^{0,2158}$ \\
\hline Physical wear ratio of capital assets & $y=466,22 x+20445$ & $y=72,38 x+840,72$ \\
\hline
\end{tabular}
represented by the period sequence number; $k$ - coefficient of $x ; b$ - quantitative parameter of the trend equation.

Table 2. Examples of trend equations for certain types of economic activity. 
The important feature in using trend analysis is the decomposition of relative indicators into absolute components, since each indicator has its own dynamics of changes. It is a result of applying the method, that a significant number of trend equations are formed, and it is complicated to present them in their entirety in the paper. Therefore, one present examples of trend equations for the indicators above that describe several types of economic activity in Ukraine below (Table 2).

Therefore, relative indicators are divided into absolute components (excluding the profitability of operating activities and the physical wear ratio of capital assets, this is explained by the peculiarities of statistical information presentation). Trend analysis allows to determine the prospective values of indicators for any period, but in our case, the period of actual information is 2013-2019, while the forecast and integral assessment of economic potential is determined for the year 2021. In addition, prospective values of relative indicators (absolute liquidity, autonomy coefficient, etc.) are calculated using their absolute components, which are determined using trend analysis.

3. Indicators normalization. The need to normalize the indicators selected for an integral assessment of economic potential is explained by the fact that they have different units of measurement. To normalize the indicators, the relation (9) was applied, which makes it possible to convert absolute indicators to relative ones. At the same time, the maximum value of the indicator equals to 1 , and the minimum value is 0 .

$$
x_{i}=\frac{x_{n}-x_{\min }}{x_{\max }-x_{\min }}
$$

where: $x_{i}$ - normalized value of the $i$-th indicator; $x_{n}$ - prospective value of the indicator for a particular type of economic activity; $x_{\min }$ and $x_{\max }$ - respectively, the minimum and maximum values of the indicator.

4. Integral assessment of economic potential. It is proposed to determine the integral indicator based on the prospective normalized values of the indicators given above (Table 1).

$$
I_{e p}=\frac{n_{1}+n_{2}+\cdots+n_{m}}{m}
$$

where: $I_{e p}$ - integral indicator for assessing economic potential unit share; $n_{1}, n_{2} \ldots n_{m}$ - normalized indicators used for integral assessment of economic potential, unit share; $m$ - number of indicators.

We further proceed to the results presentation of the research stages described above.

\section{Results}

To present the investigation results, one should apply designations for the indicators and types of economic activity of business entities. This need is explained by a significant amount of calculations (Table 3). Types of economic activity of business entities are designated as $\left(A_{1} \ldots A_{n}\right)$, and indicators are designated as $\left(F_{1} \ldots F_{n}\right)$.

Double numbering of some indicators shows that they are absolute and are used to calculate coefficients.

Using the above designations, we present the primary data for the year 2019 as the last year of the actual data array used for an integral assessment of the economic potential of business entities by type of economic activity (Table 4). At the same time, the list of indicators corresponds to the one given in Table. 1, and their decomposition is to occur at the forecasting stage. 
Table 3. Indicators and types of economic activity designation.

\begin{tabular}{|c|c|c|c|}
\hline \multicolumn{2}{|c|}{ Types of economic activity } & \multicolumn{2}{|l|}{ Indicators } \\
\hline Name & Designation & Name & Designation \\
\hline $\begin{array}{c}\text { Agriculture, forestry and fish } \\
\text { industry }\end{array}$ & $\mathrm{A}_{1}$ & $\begin{array}{l}\text { Profitability of enterprises } \\
\text { operating activities }\end{array}$ & $\mathrm{F}_{1}$ \\
\hline Industry & $\mathrm{A}_{2}$ & Financial results of enterprises & $\mathrm{F}_{2}$ \\
\hline Construction & $\mathrm{A}_{3}$ & Specific return rate & $\mathrm{F}_{3}$ \\
\hline $\begin{array}{c}\text { Wholesale and retail trade; repair } \\
\text { of motor vehicles and } \\
\text { motorcycles }\end{array}$ & $\mathrm{A}_{4}$ & Income & $\mathrm{F}_{31}$ \\
\hline $\begin{array}{l}\text { Transport, warehousing, postal } \\
\text { and courier services }\end{array}$ & $\mathrm{A}_{5}$ & Expenses & $\mathrm{F}_{32}$ \\
\hline $\begin{array}{l}\text { Temporary accommodation and } \\
\text { catering services }\end{array}$ & $\mathrm{A}_{6}$ & Capital investment & $\mathrm{F}_{4}$ \\
\hline $\begin{array}{l}\text { Information and } \\
\text { telecommunications }\end{array}$ & $\mathrm{A}_{7}$ & Capital investments in progress & $\mathrm{F}_{5}$ \\
\hline Financial and insurance activities & $\mathrm{A}_{8}$ & Current financial investments & $\mathrm{F}_{6}$ \\
\hline Real estate transactions & $\mathrm{A}_{9}$ & Absolute liquidity ratio & $\mathrm{F}_{7}$ \\
\hline $\begin{array}{l}\text { Professional, scientific and } \\
\text { technical activities }\end{array}$ & $\mathrm{A}_{10}$ & Funds & $\mathrm{F}_{71}$ \\
\hline $\begin{array}{l}\text { Administrative and support } \\
\text { services activities }\end{array}$ & $\mathrm{A}_{11}$ & Current liabilities & $\mathrm{F}_{72}$ \\
\hline Education & $\mathrm{A}_{12}$ & Coefficient of autonomy & $\mathrm{F}_{8}$ \\
\hline Healthcare and social assistance & $\mathrm{A}_{13}$ & Equity & $\mathrm{F}_{81}$ \\
\hline $\begin{array}{l}\text { Arts, sports, entertainment and } \\
\text { recreation }\end{array}$ & $\mathrm{A}_{14}$ & Total capital & $\mathrm{F}_{82}$ \\
\hline $\begin{array}{c}\text { Other types of activities and } \\
\text { unclassified ones }\end{array}$ & $\mathrm{A}_{15}$ & $\begin{array}{c}\text { Physical wear ratio of capital } \\
\text { assets }\end{array}$ & $\mathrm{F}_{9}$ \\
\hline
\end{tabular}

Among the most negative phenomena that characterize the state of Ukraine's economy should be noted such as:

1. Unprofitable activities of enterprises and other economic entities representing certain types of economic activity (in particular, this applies to the transport of warehousing, postal and courier activities, arts, sports, entertainment and recreation, etc.). In addition, sometimes there is a situation when negative financial results are accompanied by a positive value of profitability (which is possible in terms of losses not related to operating activities). This is typical of real estate transactions.

2. Relatively insignificant volumes of investments, which indicates low investment activity of enterprises. This is typical for such activities as: temporary accommodation and catering and education. This situation is explained in the first case - the traditional nature of 
services, and in the second - the limited financial resources of local budgets, which finance the activities of state educational institutions in the regions of Ukraine.

3. Unsatisfactory financial condition in some areas of economic activity, the criterion of which in our case is an indicator of absolute liquidity. These are, first of all, real estate transactions, activities in the field of administrative and support services, as well as such important activities as industry and construction. At the same time, in the first two cases low liquidity ratios are explained by insignificant amounts of cash, and in others - by a significant amount of current liabilities (which is typical of the vast majority of Ukrainian enterprises and is explained by the need to compensate receivables).

Table 4. Information for integral assessment of the economic potential, 2019.

\begin{tabular}{|c|c|c|c|c|c|c|c|c|c|}
\hline \multirow{2}{*}{$\mathbf{A}_{\mathbf{n}}$} & \multicolumn{7}{|c|}{$\mathbf{F}_{\mathbf{n}}$} \\
\cline { 2 - 10 } & $\mathbf{F}_{\mathbf{1}}$ & $\mathbf{F}_{\mathbf{2}}$ & $\mathbf{F}_{\mathbf{3}}$ & $\mathbf{F}_{\mathbf{4}}$ & $\mathbf{F}_{\mathbf{5}}$ & $\mathbf{F}_{\mathbf{6}}$ & $\mathbf{F}_{\mathbf{7}}$ & $\mathbf{F}_{\mathbf{8}}$ & $\mathbf{F}_{\mathbf{9}}$ \\
\hline $\mathrm{A}_{1}$ & 0,18 & 71003 & 1,14 & 66104 & 18134 & 2161 & 0,06 & 0,48 & 112342 \\
\hline $\mathrm{A}_{2}$ & 0,06 & 109289 & 1,03 & 199896 & 173187 & 11650 & 0,05 & 0,17 & 1479735 \\
\hline $\mathrm{A}_{3}$ & 0,03 & 4414 & 1,01 & 55994 & 54575 & 13467 & 0,05 & $-0,04$ & 52847 \\
\hline $\mathrm{A}_{4}$ & 0,24 & 68810 & 1,02 & 51818 & 22319 & 41714 & 0,07 & 0,01 & 92268 \\
\hline $\mathrm{A}_{5}$ & $-0,02$ & -24265 & 0,96 & 50078 & 30314 & 940 & 0,17 & 0,45 & 587914 \\
\hline $\mathrm{A}_{6}$ & 0,09 & 2351 & 1,06 & 2675 & 2736 & 119 & 0,11 & $-0,11$ & 9090 \\
\hline $\mathrm{A}_{7}$ & 0,13 & 14676 & 1,09 & 29885 & 9630 & 2174 & 0,23 & 0,16 & 89675 \\
\hline $\mathrm{A}_{8}$ & 0,01 & 23096 & 1,14 & 10652 & 5467 & 46578 & 0,18 & 0,43 & 3275 \\
\hline $\mathrm{A}_{9}$ & 0,18 & -1552 & 0,99 & 27557 & 34376 & 20442 & 0,04 & $-0,04$ & 211121 \\
\hline $\mathrm{A}_{10}$ & 0,09 & 20304 & 1,06 & 10798 & 26289 & 18834 & 0,1 & 0,63 & 22691 \\
\hline $\mathrm{A}_{11}$ & 0 & -493 & 1 & 11838 & 6317 & 8260 & 0,04 & 0,76 & 1149324 \\
\hline $\mathrm{A}_{12}$ & 0,06 & 138 & 1,03 & 4460 & 62 & 8 & 0,48 & 0,73 & 1199 \\
\hline $\mathrm{A}_{13}$ & 0,04 & 1022 & 1,03 & 8139 & 1207 & 227 & 0,18 & 0,34 & 6832 \\
\hline $\mathrm{A}_{14}$ & $-0,01$ & -597 & 0,96 & 3663 & 3004 & 717 & 0,07 & 0,31 & 68344 \\
\hline $\mathrm{A}_{15}$ & 0,03 & 110 & 1,02 & 572 & 1915 & 151 & 0,11 & 0,37 & 986 \\
\hline
\end{tabular}

The application of trend analysis and models, which are partially given above (Table 2), allowed to determine forecasting indicators for an integrated assessment of economic potential, in accordance with the second stage of the study (Table 5). 
Table 5. Forecasting values of indicators for integral assessment of the economic potential, 2022.

\begin{tabular}{|c|c|c|c|c|c|c|c|c|c|c|}
\hline \multirow{2}{*}{$\mathbf{A}_{\mathbf{n}}$} & \multicolumn{7}{|c|}{$\mathbf{F}_{\mathbf{n}}$} \\
\cline { 2 - 11 } & $\mathbf{F}_{\mathbf{1}}$ & $\mathbf{F}_{\mathbf{2}}$ & $\mathbf{F}_{\mathbf{3 1}}$ & $\mathbf{F}_{\mathbf{3 2}}$ & $\ldots$ & $\mathbf{F}_{\mathbf{7 1}}$ & $\mathbf{F}_{\mathbf{7 2}}$ & $\mathbf{F}_{\mathbf{8 1}}$ & $\mathbf{F}_{\mathbf{8 2}}$ & $\mathbf{F}_{\mathbf{9}}$ \\
\hline $\mathrm{A}_{1}$ & 0,16 & 109772 & 654716 & 604640 & $\ldots$ & 27449 & 742740 & 71727 & 1332348 & 157607 \\
\hline $\mathrm{A}_{2}$ & 0,12 & 292152 & 4335488 & 4679136 & $\ldots$ & 101452 & 2575875 & 171661 & 3731356 & 1285830 \\
\hline $\mathrm{A}_{3}$ & 0,03 & 10397 & 498058 & 429258 & $\ldots$ & 14315 & 306241 & -33654 & 360590 & 61350 \\
\hline $\mathrm{A}_{4}$ & 0,35 & 163601 & 8475225 & 7124554 & $\ldots$ & 127195 & 1780909 & -9564 & 2092170 & 125902 \\
\hline $\mathrm{A}_{5}$ & $-0,01$ & -27610 & 687720 & 686148 & $\ldots$ & 41522 & 298351 & 1296501 & 1494082 & 2397208 \\
\hline $\mathrm{A}_{6}$ & 0,17 & 8574 & 63340 & 52298 & $\ldots$ & 3810 & 29438 & -8821 & 38617 & 11185 \\
\hline $\mathrm{A}_{7}$ & 0,28 & 36987 & 209498 & 176599 & $\ldots$ & 18185 & 88017 & 38411 & 203511 & 147200 \\
\hline $\mathrm{A}_{8}$ & 0,08 & 50542 & 173843 & 134724 & $\ldots$ & 23578 & 141122 & 112711 & 330470 & 4153 \\
\hline $\mathrm{A}_{9}$ & 0,72 & 10949 & 218266 & 147802 & $\ldots$ & 14070 & 422314 & -70133 & 583432 & 387470 \\
\hline $\mathrm{A}_{10}$ & 0,34 & 66564 & 442726 & 289557 & $\ldots$ & 44795 & 527461 & 700587 & 1137070 & 24175 \\
\hline $\mathrm{A}_{11}$ & 0,15 & 795 & 168146 & 148987 & $\ldots$ & 4432 & 186992 & 326553 & 363330 & 2299841 \\
\hline $\mathrm{A}_{12}$ & 0,05 & 198 & 7445 & 7235 & $\ldots$ & 536 & 1123 & 2446 & 3436 & 1420 \\
\hline $\mathrm{A}_{13}$ & 0,07 & 2108 & 99552 & 83788 & $\ldots$ & 2405 & 12338 & 4726 & 14250 & 9181 \\
\hline $\mathrm{A}_{14}$ & 0,02 & -1006 & 10599 & 11160 & $\ldots$ & 962 & 20566 & 6687 & 37780 & 112439 \\
\hline $\mathrm{A}_{15}$ & 0,04 & 160 & 6086 & 6756 & $\ldots$ & 758 & 5166 & 3242 & 8308 & 1323 \\
\hline
\end{tabular}

Based on these calculations, in the study the normalization of indicators selected as criteria for assessing economic potential was carried out. At the same time, such relative indicators as: specific profitability, absolute liquidity and autonomy ratio were determined on the basis of forecasting values of their absolute components (Table 6).

The results of normalization of forecasting indicators that characterize the economic potential, allow us to present the most serious problems in the activities of enterprises and other economic entities (because the lowest values of indicators are zero). Thus, the transport sector is expected to be the least profitable, educational activities will not be investment-oriented in the future, and real estate entities will have problems with capital structure. But this is confirmed by the actual data of 2019 , which indicates the persistence of negative phenomena in the near future. At the same time, the industry demonstrates the highest potential among the presented types of economic activity. 
Table 6. Forecasting normalized values of indicators for integral assessment of the economic potential, 2022.

\begin{tabular}{|c|c|c|c|c|c|c|c|c|c|}
\hline \multirow{2}{*}{$\mathbf{A}_{\mathbf{n}}$} & \multicolumn{7}{|c|}{$\mathbf{F}_{\mathbf{n}}$} \\
\cline { 2 - 10 } & $\mathbf{F}_{\mathbf{1}}$ & $\mathbf{F}_{\mathbf{2}}$ & $\mathbf{F}_{\mathbf{3}}$ & $\mathbf{F}_{\mathbf{4}}$ & $\mathbf{F}_{\mathbf{5}}$ & $\mathbf{F}_{\mathbf{6}}$ & $\mathbf{F}_{\mathbf{7}}$ & $\mathbf{F}_{\mathbf{8}}$ & $\mathbf{F}_{\mathbf{9}}$ \\
\hline $\mathrm{A}_{1}$ & 0,2184 & 0,4296 & 0,2896 & 0,2963 & 0,1348 & 0,0663 & 0,2504 & 0,021 & 0,068 \\
\hline $\mathrm{A}_{2}$ & 0,1569 & 1 & 0,0408 & 1 & 1 & 0,3014 & 0,2435 & 0,035 & 0,5588 \\
\hline $\mathrm{A}_{3}$ & 0,047 & 0,1189 & 0,413 & 0,1958 & 0,2936 & 0,3329 & 0,1198 & 0,0775 & 0,0261 \\
\hline $\mathrm{A}_{4}$ & 0,4645 & 0,598 & 0,4596 & 0,2618 & 0,1037 & 0,038 & 0,1986 & 0,2199 & 0,0542 \\
\hline $\mathrm{A}_{5}$ & 0 & 0 & 0,1614 & 0,3434 & 0,159 & 0,0139 & 0,9725 & 0,6108 & 0,424 \\
\hline $\mathrm{A}_{6}$ & 1 & 0,1132 & 0,4939 & 0,0086 & 0,0125 & 0,0007 & 0 & 0,5546 & 0,0043 \\
\hline $\mathrm{A}_{7}$ & 0,3708 & 0,202 & 0,4544 & 0,0962 & 0,0736 & 0,038 & 0,3701 & 1 & 0,0635 \\
\hline $\mathrm{A}_{8}$ & 0,1044 & 0,2444 & 0,6201 & 0,0386 & 0,0363 & 1 & 0,5052 & 0,7718 & 0,0012 \\
\hline $\mathrm{A}_{9}$ & 0,9302 & 0,1206 & 0,9168 & 0,1102 & 0,1839 & 0,5547 & 0,096 & 0 & 0,168 \\
\hline $\mathrm{A}_{10}$ & 0,4476 & 0,2945 & 1 & 0,082 & 0,1282 & 0,9741 & 0,7492 & 0,2978 & 0,0099 \\
\hline $\mathrm{A}_{11}$ & 0,2069 & 0,0888 & 0,3625 & 0,0542 & 0,0334 & 0,1812 & 1 & 0,0555 & 1 \\
\hline $\mathrm{A}_{12}$ & 0,0686 & 0,087 & 0,2039 & 0,017 & 0 & 0 & 0,8341 & 2,5632 & 0 \\
\hline $\mathrm{A}_{13}$ & 0,098 & 0,0929 & 0,4573 & 0,0385 & 0,0045 & 0,0061 & 0,4969 & 0,9327 & 0,0034 \\
\hline $\mathrm{A}_{14}$ & 0,0274 & 0,0832 & 0,0777 & 0,0293 & 0,0155 & 0,0134 & 0,3597 & 0,0778 & 0,0483 \\
\hline $\mathrm{A}_{15}$ & 0,0547 & 0,0868 & 0 & 0 & 0,0085 & 0,0037 & 0,5489 & 0,6539 & 0 \\
\hline
\end{tabular}

The integral indicator that characterizes the economic potential of Ukraine by types of entities 'economic activity is the result of generalization of promising normalized values of indicators, in accordance with the final stage of the research. The results of ranking economic activities depending on the value of the integrated indicator of economic potential are presented below (Fig. 1).

The maximum level of realization of economic potential is $48 \%$, which indicates significant unrealized opportunities for the Ukrainian economy. 


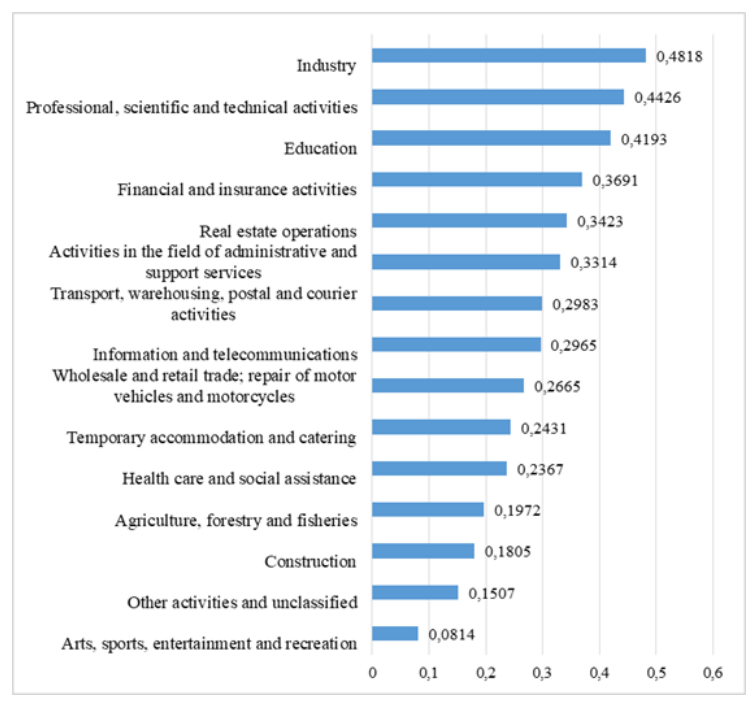

Fig. 1. Results of the prospective integrated assessment of the economic potential in 2022 .

In the process of planning the development of the economy can take into account several opposite principles: a) priority financing of the most developed sectors of the economy to maximize the economic effect and rapid reinvestment of funds; b) priority financing of the least developed industries to ensure integrated economic development, taking into account not only economic but also social consequences of the implementation of state policy in this area.

\section{Conclusions}

According to the results of the analysis of official information from open sources, the paper substantiates the list of indicators for the integrated assessment of the economic potential of Ukraine, taking into account the division of economic entities by type of economic activity.

Based on the application of trend analysis (namely - exponential, logarithmic, power and other trend models that take into account the dynamics of economic indicators), the paper calculates the long-term values of the previously selected criteria for assessing the economic potential of Ukraine. At the same time, some relative indicators (specific profitability, absolute liquidity and autonomy ratio) were calculated using their absolute components. This allows to increase the validity of the calculations, taking into account the individual dynamics of changes in absolute indicators used to determine the coefficients.

To ensure the correctness of the calculation of the integrated indicator of economic potential, the paper normalizes the forecasting values of economic indicators. The results of this stage of the study also provide an idea of the problems of economic entities representing a particular type of economic activity.

As a result of generalization of normalized indicators in the work the integrated indicator of economic potential is defined. The ranking of economic activities according to this indicator indicates that the most perspective economic activities in the Ukrainian economy are industry, professional, scientific and technical activities and education. Construction, art, sports, entertainment and recreation, as well as other activities are conventionally considered "outsiders". The results of the integrated assessment of economic potential can be used to determine the amount of public funding for economic development by type of economic activity of economic entities. 


\section{References}

1. J. D. Hamilton Measuring global economic activity. (NBER working. paper, 2019), http://www.nber.org/papers/w25778

2. L. Kilian, X. Zhou, JIMF 88, 54-78 (2018)

3. O. Dymchenko, I. Tararuiev, V. Yesina, Development of the Evaluation Methodology of the Regional Competitiveness Index in Ukraine, in Proceeding of the 12 th International Scientific Conference, PEA, Ostrava, Czech Republic (2017)

4. C. Serbanica, D. Constantin, FCESifo, 19, 24-31 (2018)

5. A. Brown, R. Fornoni, B. Gardiner, L. Greunz, S. Jestl, N. Rabemiafara, R. Römisch, J. Stenning and T. Ward, Economic Challenges of Lagging Regions, Luxembourg (Publications Office of the European Union, 2017)

6. W. R. Kerr, R. Nanda. ARF1 7, 445-462 (2015)

7. The State statistics service of Ukraine (2021), http://www.ukrstat.gov.ua

8. V. M. Babayev, M. K. Sukhonos, O. V. Dymchenko, Iu. O. Tararuiev, V. O. Yesina, O. O. Rudachenko, O. Yu. Palant, Ye. N. Vodovozov, Zh. P. Beztsinna, Potential of business entities: essence, assessment and role in national development (VUZF Publishing House "St. Grigorii Bogoslov", Sofia, 2021)

9. V. Koval, G. Duginets, O. Plekhanova, A. Antonov, and M. Petrova, On the supranational and national level of global value chain management. J. Entrep.. Sustain. Issu. 6, 1922 (2019)

10. N. Shmygol, O. Galtsova, O. Solovyov, V. Koval, and I. W. E. Arsawan, Analysis of country's competitiveness factors based on inter-state rating comparisons. E3S Web Conf. 153, 03001 (2020)

11. O. V. Prokopenko, N. V. Biloshkurska, M. V. Biloshkurskyi, and V. A. Omelyanenko, Financ. Credit Act. Probl. Theory Pract. 3, 26 (2019) 